\title{
Nyaralás alatti munkavégzés: a workcation turizmus elméleti és gyakorlati kérdései
}

\author{
Szerzők: Pécsek Brigitta ${ }^{1}$
}

Munka, szabadidó és alvás a három fố tevékenység, melyek ciklikus váltakozásai mentén éli életét a modern ember. A három alaptevékenység a múltban egyértelmúen elkülönült egymástól. A határok elmosódása a késômodernitás trendje, melynek következményeképpen napjainkban két, egymással ellentétes, utazási forma terjedésének lehetünk tanúi: a staycation (turizmus az otthon elhagyása nélkül) és a workcation (nyaralás alatti munkavégzés). A tanulmány ez utóbbi jelenséget vizsgálja meg elméleti és gyakorlati oldalról: a szerzố elöször egy saját workcation koncepciót fogalmaz meg, majd a szakirodalom és az online kérdôives megkérdezés elemzésének eredményeként hat különbözô workcation turista típust különit el és jellemez. Ezek alapján meghatározza azt a szegmenst, mely igények figyelembevételével egy adott település fenntartható turisztikai fejlesztéseket vihet végbe. A szerzô zárásként egy külföldi példát is bemutat, ahol ezek a fejlesztések már megvalósultak, és sikeresen müködnek.

Kulcsszavak: workcation, nyaralás, stressz, digitális nomád.

\section{Bevezetés}

Jelen tanulmány célkitûzése kettős, mivel az elméleti háttér elemzése és a ráépülő empirikus kutatás segítségével egy turizmusközpontú elméleti keretet is nyújt - egy koncepció és egy tipizálás formájában - a workcation jelenséget vizsgálni szándékozó társadalomkutatóknak. A szakirodalom gazdag a munka és a magánélet egyensúlyát, illetve az egyensúlytalanságuk negatív következményeit taglaló tanulmányokban (NIPPERT-ENG 1996, HOUSTON 2005, FLEETWOOD 2007, MESSERSMITH 2007, SÜSS-SAYAH 2013, HAAR et al. 2014, JAMES 2014, SARDESHMUKH-SRINIVASAN 2014, AUAHMED 2015, MARAGATHAM-AMUDHA 2016, BEIGI-SHIRMOHAMMADI 2017). Azonban a turizmusfókuszú, szabadság alatti munkavégzést elemző kutatások száma elenyésző, és a meglévők is a munka felőli megközelítést alkalmazzák, a workcation koncepciója elkerülte a turizmuskutatók fő sodrát. A kutatások csekély száma a fogalmi keretek hiányának tudható be, a kifejezést még napjainkban is csak az internetes alternatív (urbánus és szleng) szótárak tartalmazzák, ahol az alábbi általános definíció olvasható: „fizetett üzleti

\footnotetext{
$\overline{1}$ óraadó, Kodolányi János Egyetem, bpecsek@kodolanyi.hu
}

út, mely nyaralással kombinálható. A work + vacation összetételéból keletkezett szó"2 ${ }^{2}$. Egy másik gyakran olvasható definíció szerint: „a munka és a vakáció kombinációja”3. Ezek a fogalom magyarázatok egyedül a digitális nomádra vonatkozhatnak, mely a workcation turisták később taglalt hat lehetséges csoportja közül csak az egyik. Ez a szúk perspektíva nem meglepő, hiszen ez egy jól látható csoport, így igényei is könnyen felmérhetőek. Ugyanakkor a turisták többsége szabadidős céllal indul útnak, még akkor is, ha nyaralása során munkával kapcsolatos tevékenységet is folytat. Az elméleti részben olvasható a workcation turizmus egyik lehetséges definíciója, melyet a szabadság alatti munkavégzés és a stressz összefüggéseinek a taglalása követ. A tanulmány második részében az online kérdőíves kutatásba bevont 340 magyar nyelvú személy válaszai alapján a workcation turisták kategorizálására kerül sor. Végül egy múködő külföldi gyakorlat leírásán keresztül egy konkrét turisztikai fejlesztési javaslat is megfogalmazódik.

\section{Elméleti háttér}

\subsection{A WORKCATION KONCEPCIÓJA}

A határok elmosódása a mai, posztmodern társadalom számos területén érzékelhetô, melynek

\footnotetext{
${ }^{2} \mathrm{http}: / /$ onlineslangdictionary.com/meaning-definition-of/workation

${ }^{3}$ https://www.wordnik.com/words/workcation
} 
egyik kritikusa BAUMANN (2000), aki saját fluiditás elméletén keresztül vizsgál különböző társadalmi folyamatokat. Leszögezi, hogy a modern világ állandó változása az egyént identitásában bizonytalanítja el, melynek következtében gyökérverésre is képtelenné válik. Ez a modern fluiditás ECO (2017) utolsó múvében is megjelenik, aki szintén a modern társadalom folyékonyságáról ír.

A határok lebontása a munka és a szabadidó viszonyában is megmutatkozik. Napjainkban az alternatív munkaidô rendszerek - a rövidített munkahét, a rugalmas munkaidó, a távmunka, a munkakör megosztás, a speciális foglalkoztatási programok, illetve a munkaerő kölcsönzés - terjedésének lehetünk tanúi. A technika fejlődésével együtt ez a rugalmasabb rendszer sokak számára lehetővé teszi a munkahelyen kívüli munkavégzést, mely utat nyitott a workcation jellegú nyaralásoknak. Korábban a hivatásturizmus volt az egyetlen, ahol az utazás során munkavégzés történt, így az nem is sorolódott a szabadidős turizmus ernyője alá. Az üzleti célú utazásoknál, ha egy üzletember a célterületen szabadidôs turistaként szándékozott viselkedni, ezt az üzleti út előtt vagy után a saját pénzügyi forrásából tehette meg. Napjainkban az számít kivételnek, ha valaki teljesen nyaraló üzemmódba kapcsol, és kollégáival, üzleti partnereivel nyaralása alatt egyáltalán nem tart kapcsolatot.

A fent említett fluiditás konkrét turisztikai leképeződése két ellentétes hibrid trend megjelenése: a staycation (turizmus az otthon elhagyása nélkül) és a workcation (nyaralás alatti munkavégzés) jelensége. A staycation a 2008-as nemzetközi pénzügyi válság idején került a turizmuskutatók homlokterébe, amikor többnyire anyagi megfontolásból egyre többen fedezték fel lakóhelyük természeti és kulturális vonzerejét, és lakhelyükön vagy ahhoz közel nyaraltak. Turizmuselméleti szempontból az újdonság ereje abból fakad, hogy felteszi a kérdést: a turisztikai élmény megszerzéséhez és átéléséhez szükséges-e a fizikai eltávolodás vagy elég az agy turisztikai üzemmódba való átállítása. Jelen tanulmány központi témája, a workcation, pont a másik oldalt feszegeti, vagyis szükséges-e a munka százszázalékos hátrahagyása a kikapcsolódáshoz. A turizmuskutatás egyik hiányossága a szabadság alatti munkavégzés tudományos alapokon történố vizsgálata, melynek következménye a téma bulvár, illetve ismeretterjesztô média általi kisajátítása. Általánosan elfogadott definíció hiányában a saját elméleti és empirikus kutatásaimra támaszkodva az alábbi workcation definíciót fogalmaztam meg: A workcation a turizmus hibrid típusa, mivel a turista szabadidôs vagy kettôs (üzleti és szabadidôs) motivációval indul útnak, és otthonától távol, a modern techni- kának köszönhetôen, munkavégzést és szabadidôs tevékenységeket is folytat.

A koncepció fó elónye, hogy az utazók teljes spektrumát lefedi, akik nyaralásuk során bármilyen munkával kapcsolatos tevékenységet végeznek. Az alternatív és szubkultúrával foglalkozó ismeretterjesztó és szórakoztató magazinok cikkeikben csupán a jelenség fiatalos, trendi részével foglalkoznak, és figyelmen kívül hagyják a turizmusfejlesztôk számára fontos egyéb szegmenseket.

\subsection{A MUNKÁVAL TÖLTÖTT NYARALÁS ÉS A STRESSZ KAPCSOLATA}

A szakirodalomban a workcation nem egyértelmúen negatív trendként jelenik meg. A tudományokon átíveló, gyakran mozaikos szakirodalom a jelenség pozitív és negatív oldalát is megvilágítja. Az elemzés nem tér ki az orvosi szempontú kutatásokra, melyek meghaladnák jelen tanulmány kereteit.

A nyaralás alatti munkavégzés negatív hatásaival számos tanulmány foglalkozott az utóbbi évtizedben (NEULINGER 1982, GILBERT-ABDULLAH 2004, DECI-RYAN 2008, MARSHALL 2012), melyek szerzói leszögezik, hogy a teljes kikapcsolódás hiánya már önmagában is stressz forrása és betegségek kiváltója, mivel a dolgozó képtelenné válik frissen és megújulva visszatérni a munkába. Holott az utazás lényege pont a stressz csökkentése és a jóllét növelése lenne, ahogy CSÍKSZENTMIHÁLYI (2014) flow elméletében vagy MICHALKÓ $(2010,2014)$ az utazás és a jóllét kapcsolatát elemzô számos munkájában bizonyítást nyert.

A menedzser-kutatásokkal foglalkozó SILVERMAN (2015) szerint az alkalmazottak oldaláról elhangzó gyakori ellenérv a párhuzamos cselekvések rossz hatékonyságú outputja és alacsony minősége. Ugyanis a félig munka/félig nyaralás kombináció azt eredményezheti, hogy az egyén egyik szituációban sem nyújt $100 \%$-ot. A szerzó úgy véli, hogy a hagyományos nyaralás elmaradása ugyanolyan kiégést okozhat, mintha az illetó el sem utazott volna.

A fentieket erősíti meg az a felmérés is, mely a munkavállalók elégedetlenségét a szabadság alatti munkaelvárások szempontjából vizsgálta ${ }^{4}$. A teljes kikapcsolódást nem támogató munkaadók alkalmazottainak 40\%-a keres aktívan új munkahelyet, szemben a pihenést támogató és elősegítő cégekkel, ahonnan a munkaerố $21 \%$-a kíván távozni. Vagyis a teljes kikapcsolódáshoz való jog tisztelet-

${ }^{4} \mathrm{https:/projecttimeoff.com/wp-content/uploads/2018/04/StateofAmeri-}$ canVacation2017.pdf 
Lektorált tanulmányok

ben tartása a munkahelyhez való lojalitást is erôsíti az alkalmazottakban. A támogató munkahelyek dolgozóinak 69\%-a érzi magát elismertnek, 64\%-a érzi úgy, hogy a vezetőség törődik vele, és 73\%-a véli úgy, hogy munkáját fontosnak ítélik meg. A másik csoportnál ezek az arányok lényegesen alacsonyabbak ( $50 \%$, $43 \%$ és $57 \%$ ).

A különbözô idők (munkaidő és szabadidó) ilyen intenzív összemosódásának hosszú távú negatív hatásai a téma frissessége miatt még nem bizonyíthatóak. Vannak kutatások arra vonatkozóan is, hogy a munka és a privát élet kiegyensúlyozása szempontjából még a dolgos nyaralás is kedvezóbb a test és lélek szempontjából, mintha egyáltalán nem történne helyváltoztatás (NAWIJN-DAMEN 2014). A kutatópáros 374 holland nemzetiségút kérdezett meg nyaralási szokásaikról, akiknek $97 \%$-a elégedett volt a szabadság alatti munka/szabadidó arányával. Véleményük szerint egy munkával eltöltött nyaralás kevésbé stresszes, mint a „láblógatós" szabadság utáni első napok, melyek gyakran a feltornyosult elvégzendők miatt válnak stressz forrásává. A munkavállalók mellett a cégvezetók és a kisvállalkozók egy része is úgy vélte, hogy bizonyos mennyiségú nyaralás alatti munka szükséges a zökkenőmentes üzletmenet fenntartásához.

Tágabb kontextusba helyezve érdemes kitérni a holland munkaerő-piaci és jogi szabályozás néhány sajátosságára. A hollandok átlag 20 nap fizetett szabadsága az egyik legrövidebb az Európai Unióban, ennek ellenére a hollandok az egyik leggyakrabban utazók. 70\%-uk utazott el nyári szabadságra 2017-ben és 50\%-uk külföldön pihent. A munkaidó hossza tekintetében a heti átlag 38 órás munkaidôvel (az EU átlag 40,3 óra, az amerikai 47 óra) a legkevesebbet dolgozók közé tartoznak. Ezen felül a nók 74\%-a csupán részmunkaidőben dolgozik, és a csökkenó munkaidô a férfiaknál is tendencia (PIETERS 2017). Elképzelhetô, hogy a hollandokat azért zavarja kevésbe a nyaralás alatti munkavégzés, mert a hétköznapokban is képesek megtalálni a munka-szabadidő egyensúlyát, és napi szinten jut idejük kikapcsolódásra. A kiegyensúlyozottsághoz hozzátartozik, hogy a hollandok nagyrészének maga a munkábajárás is kevésbé stresszes, mivel nagyszámban használnak kerékpárt, és a sport köztudottan jóllétet növelő tényezô a termelődő boldogsághormonoknak köszönhetően.

A kérdés összetettségét jól mutatja a felsőoktatásban dolgozó oktatók és kutatók szabadság alatti munkavégzéshez való viszonya. A ResearchGate ${ }^{5}$ kérdőíves megkérdezésének eredménye rámutatott, hogy a válaszadók mindegyike dolgozik nyaralása alatt. Az okokat keresve a döntő érv: „A

\footnotetext{
https://www.researchgate.net/post/Do_you_continue_doing_research_during_holiday_time
}

nyaralás alatt több idő jut kutatásra". A hozzászólásokból az is kiviláglik, hogy a megkérdezettek kifejezetten kedvelik és várják ezeket a dolgos nyaralásokat, mert a mozgalmas szorgalmi idószak után végre lelassulhatnak, szakirodalmat olvashatnak és tanulmányokat írhatnak. Úgy vélem, hogy sokuk számára az olvasás és írás lassú folyása - szemben a szigorú tantervek mentén tartott elóadások és számonkérések menetrendjével - már eleve kikapcsoló hatású. Az elemzés hiányossága, hogy nem tér ki a munkavégzés fogalmának lehatárolására, példának okán, hogy egy történész nyaralás során írt történelmi témájú detektívregénye mennyiben tekinthető munkának vagy szabadidôs tevékenységnek.

A 2017-ben készült amerikai Project: Time Off kutatás ${ }^{6}$ olyan kérdéseket feszegetett, melyek eddig empirikusan nem kerültek terítékre. Ilyen például a munkamártírok teljesítményének és jutalmazásának vizsgálata. A kutatás munkamártíroknak nevezte azokat a kollégákat, akik azért mondanak le szabadságukról, mert úgy érzik, hogy senki nem képes ideiglenesen a helyükre lépni. A szerzők arra is rámutattak, hogy ezek az alkalmazottak nemcsak alacsonyabb színvonalú munkát tettek le az asztalra, mint társaik, de ennek következtében kisebb mértékben is kaptak jutalmat fizetésemelés vagy bónusz formájában.

Az empirikus kutatások egyik tanulsága, hogy a workcation-höz való hozzáállást nagyban befolyásolja a válaszadó foglalkozása, munkaviszonyának jellege és a munkához/feletteséhez való hozzáállása. A teljes állású alkalmazottak a szabadság alatti munkavégzést inkább negatívan élik meg, mert úgy érzik, hogy még a szabadidejükkel sem ók rendelkeznek. A kisvállalkozók és a felső vezetók, akik pozíciójukból adódóan társadalmi idejükkel szabadabban rendelkeznek, a felsőoktatásban dolgozókhoz hasonlóan, bár eltérő okból kifolyólag, a nyaralás alatti munkavégzés pozitív oldalát emelték ki. További elemzés tárgya lehet, hogy ha az alkalmazottak is megkapnák ezt a döntési szabadságot, az hogyan befolyásolná a workcation-höz való viszonyukat.

\section{Módszer}

A kutatás 2017 októberében online kérdőíves megkérdezés keretében zajlott, melyben 230 férfi és 110 nő, összesen 340 fó vett részt. A módszer egyik elónye, hogy a megfeleló platformot választva rövid idő alatt nagyszámú kitöltött kérdőív érkezett vissza, és mivel a technika nem engedett kérdéskihagyást, így a kérdőívek mind feldolgozhatóak

${ }^{6} \mathrm{https} / /$ projecttimeoff.com/wp-content/uploads/2018/04/StateofAmericanVacation2017.pdf 
voltak. Fó hátrányként az anonimitásból adódóan előforduló illetéktelen kitöltések, illetve a reprezentativitás hiánya hozható fel. Azonban a téma újdonsága és a kutatás dominánsan elméleti jellege miatt sem az online megkérdezés, sem a kényelmi minta nem volt gátló tényező. Ezt támasztja alá FRICKER (2012) kutatása is, aki az internetes kutatási módszereket hasonlította össze a hagyományos módszerekkel, és érvényességben nem talált különbséget a két módszer között. Ráadásul ez a téma szorosan kötődik a virtuális világhoz, így nem véletlen, hogy a tanulmányban idézett munkák szintén az online megkérdezéses módszert és a kényelmi mintavételt választották.

A 12 kérdéses, magyar nyelvú kérdôív az utazások gyakoriságára, a nyaralásra vitt technikai eszközökre, a munkavégzés gyakoriságára és a nyaralás alatti stresszre kérdezett rá. A minta demográfiai jellemzőit az 1. táblázat foglalja össze, melyben a nemzetközi szakirodalomban elterjedt kategóriákat alkalmaztam. Ennek fó oka, hogy a modern technológiával kapcsolatos magyar nyelvú irodalom szintén ezt a csoportosítást használja (TARI 2010, 2011), másrészt ily módon a nemzetközi összehasonlítások is könnyebben kivitelezhetőek.

1. táblázat

A válaszadók demográfiai mintája

\begin{tabular}{|l|c|c|}
\hline \multicolumn{1}{|c|}{ Kor } & $\boldsymbol{d} \boldsymbol{b}$ & $\boldsymbol{\%}$ \\
\hline 1945 előtt született & 21 & 6 \\
\hline Baby boomer (1946-1964) & 59 & 17 \\
\hline X generáció (1965-1979) & 152 & 45 \\
\hline Y generáció (1980-1994) & 88 & 26 \\
\hline Z generáció (1995-2009) & 20 & 6 \\
\hline$N=$ & 340 & 100 \\
\hline
\end{tabular}

\begin{tabular}{|l|c|c|}
\hline \multicolumn{1}{|c|}{ Foglalkozás } & $\boldsymbol{d} \boldsymbol{b}$ & $\boldsymbol{\%}$ \\
\hline Beosztott alkalmazott & 109 & 32 \\
\hline Középvezetó & 62 & 18 \\
\hline Felsó vezetố & 63 & 19 \\
\hline Nyugdijas & 61 & 18 \\
\hline Diák & 22 & 6 \\
\hline Vállalkozó & 23 & 7 \\
\hline$N=$ & 340 & 100 \\
\hline
\end{tabular}

Forrás: saját szerkesztés

A korosztályos bontást vizsgálva az $\mathrm{X}$ és az $\mathrm{Y}$ volt a legaktívabb generáció, mintegy 71\%-os aránnyal. A foglalkozási megoszlást tekintve a közép- és felsô vezetôk, valamint a nyugdíjasok hasonló arányt képviseltek, viszont elenyészó volt a diákok és a vállalkozók aránya. Az utóbbiak alacsony száma azért is meglepó, mivel a KSH kimutatása szerint a nyilvántartásba vett önálló vállalkozók száma 2015 végén 1130000 voltt$^{7}$. Csekély számuk a mintában nem teszi lehetővé, hogy külön vizsgálat alá essenek, pedig országosan 97,9\%-uk mikro vállalkozás, vagyis tíz főnél kevesebb foglalkoztatottal múködik, melyek vezetői saját maguk döntenek időbeosztásukról, így szabadabbak e tekintetben, mint egy alkalmazott, ugyanakkor a csábítás is nagyobb a szabadidós munkavégzésre. Meglepó módon a nemzetközi kutatásokban szintén nem lelhetők fel vállalkozókra vonatkozó felmérések, mely azt valószínúsíti, hogy ezt a réteget csak célzottan, más eszközökkel lehet megszólítani.

A téma korosztályos vizsgálatához kapcsolódó nemzetközi kutatási eredmények korlátozottan állnak rendelkezésre. A már idézett amerikai Project: Time Off vizsgálat a mostani mintához hasonló módon az X és az Y generációt találta legaktívabbnak a nyaralása alatt. Az X generáció $82 \%$-a azzal érvelt, hogy kisebb lelkiismeretfurdalással vesz ki szabadságot, ha pihenés közben is állandóan elérhetô. Ez az Y generációnál is fontos szempontnak számított, de az arány (77\%) kissé alacsonyabb volt.

\section{Eredmények}

Ez a fejezet a megkérdezettek utazási szokásaival kapcsolatos kérdések elemzéseit, valamint a kérdőíves kutatás és a szakirodalom alapján a hat workcation turista típust mutatja be. Az első kérdés a megkérdezettek utazási gyakoriságára vonatkozott.

2. táblázat

\section{A nyaralás gyakorisága}

\begin{tabular}{|l|c|}
\hline \multicolumn{1}{|c|}{ A nyaralás gyakorisága/év } & $\%$ \\
\hline kevesebb mint egyszer & 3 \\
\hline egyszer & 41 \\
\hline 2-3 alkalommal & 47 \\
\hline több mint háromszor & 9 \\
\hline
\end{tabular}

Forrás: saját szerkesztés

A 2. táblázat szerint a felmérésben résztvevők közel fele évente 2-3 alkalommal megy nyaralni, vagyis a nyári szabadságon kívül feltételezhetően még 1-2 rövidebb nyaralást is tesz. Alig kevesebb azoknak a száma, akik évi egy alkalommal, valószínúleg nyáron utaznak. Csupán elenyészô számban vannak olyanok, akik nem vesznek részt turisztikai jellegú utazásokban évi rendszerességgel, és azoknak a száma is $10 \%$ alatt van, akik gyakran, 3 alkalom-

\footnotetext{
${ }^{7}$ https://www.ksh.hu/docs/hun/xftp/gyor/gaz/gaz1512.pdf
} 
Lektorált tanulmányok

nál többször kelnek útra. Tehát az utazás kortól és foglalkozástól függetlenül gyakori szabadidős tevekénységnek bizonyult a válaszadók körében. Ebben a tekintetben a minta reprezentatívnak tekinthetó, mivel a magyar lakosság 2017-ben 20 millió alkalommal utazott, vagyis a 10 millió főre vetítve átlagban 2 alkalommal indultunk útnak ${ }^{8}$. A Danubius Hotels 6500 fós mintán végzett felmérése alátámasztja a fenti arányokat, mely szerint a válaszadók fele (53\%) évente többször is elutazik

\subsection{AZ UTAZÁSRA ELVITT TECHNIKAI ESZKÖZÖK}

A modern technológia felelőssége vitathatatlan abban, hogy a mai ember hogyan és mennyi időt tölt munkával és pihenéssel. Mivel napjainkban a hivatalos és a magánélet is azonos virtuális térben folyik, bizonyos összemosódás elkerülhetetlen, és gyakran az egyén logisztikai képességére van bízva, hogy mennyire képes a kettót különválasztani. A következó kérdés a leggyakrabban használt technikai eszközre vonatkozott.

3. táblázat

Utazásra elvitt technika

\begin{tabular}{|l|c|c|c|}
\hline \multicolumn{1}{|c|}{ Gyakoriság } & \multicolumn{3}{|c|}{ Eszközö̈k } \\
\hline & mobil & tablet & laptop \\
\hline mindig & $91 \%$ & $6 \%$ & $15 \%$ \\
\hline néha & $9 \%$ & $29 \%$ & $41 \%$ \\
\hline soha & $0 \%$ & $65 \%$ & $44 \%$ \\
\hline
\end{tabular}

Forrás: saját szerkesztés

Amint látható (3. táblázat), egyértelmúen a mobil telefonok vették át a számítógépek szerepét a nyaralás idejére. Ehhez az okostelefonok multifunkciója mellett a diszkont légitársaságok szigorú csomaglimitje is hozzájárult, mely nem teszi lehetővé nehéz laptopok szállítását. Ugyanakkor minden informatikai újdonság, így a tablet kifejlesztéséhez is hoszszú évek kutatómunkája volt szükséges, melynek versenyképtelensége a szakembereket is meglepte. Ha a 2012-13 környékén íródott optimista cikkeket és kísérleteket (ARTHUR 2012) összehasonlítjuk a frissebb írásokkal (HOWARTH 2015, STATT 2015, TITCOMB 2017, EDGY $\mathrm{LABS}^{10}$ ), két teljesen ellenkező kép tárul elénk.

A tablet kudarcának okai az egyre könnyebb laptopok, illetve az egyre nagyobb okostelefonok, így a tabletek méretelónye a telefonnal, illetve súlyelônye a laptoppal szemben kezd eltúnni.

\footnotetext{
${ }^{8} \mathrm{http}: / / w w w . k s h . h u / d o c s / h u n / x f t p / i d o s z a k i / j e l t u r / j e l t u r 17 . p d f$

${ }^{9} \mathrm{https} / / / \mathrm{www}$. danubiushotels.com/hu/magazin/kutatas

${ }^{10} \mathrm{https} / / /$ dgylabs.com/notebook-vs-tablet-vs-laptop-whats-thebest-mobile-pc
}

Ugyanakkor nem vált 100\%-os laptop helyettesítơvé sem, mert kevesebb funkció érhető el vagy nehézkes rajta (írás), így komfortban nem sokkal múlja felül a mobiltelefont. Az iparág proaktív válasza a legújabb technikai találmány, a hibrid számítógép, mely a laptop és a tablet elónyeit egyesíti, így mindkét eszközt kiválthatja.

\subsection{A NYARALÁS ALATT VÉGZETT TEVÉKENYSÉGEK}

A következő kérdéskör a nyaralás alatt végzett konkrét tevékenységekre kérdezett rá, melyek arányát és az említések számát az 1. ábra mutatja. A két passzív tevékenység végzett az élen, az e-mail és az SMS olvasása, mely inkább csak a munkaesemények követését jelenti, és nem aktív bekapcsolódást a munkafolyamatokba. Az egyetlen teljes figyelmet igényló tevékenység a videokonferencia, melyen a válaszadók $10 \%$-a vett már részt utazásai során. A többi munka tevékenység szabadidős tevékenységekkel párhuzamosan is végezhető, vagyis a dolgozó felet nem vonja ki a vele együtt utazók társaságából.

\section{Nyaralás alatt végzett tevékenységek}

1. ábra

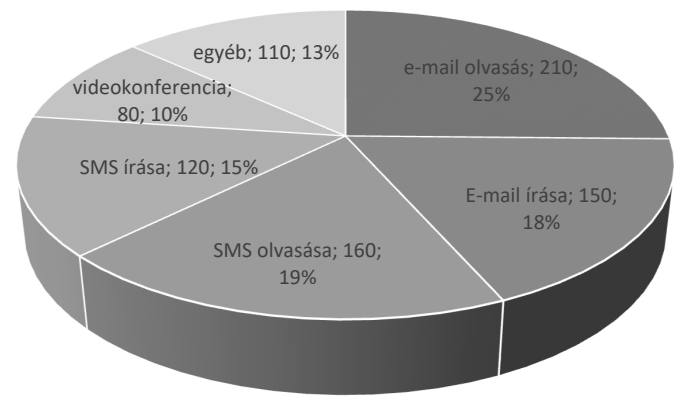

Forrás: saját szerkesztés

A napjainkban elvárt multitasking, azaz a párhuzamos tevékenységekre való képesség is kedvező talajt teremt a nyaralás alatti munkavégzéshez. Az álláshirdetések gyakori elvárása a figyelem megosztására való hajlandóság, mely minden alkalommal mint pozitív, kívánatos követelmény jelenik meg. A tanulmány terjedelme nem teszi lehetôvé a téma kifejtését, csak két irodalmat idéznék fel, melyek szerint a multitasking nemcsak természetellenes, hanem az elvégzett munka minőségét is rontja. BRADBERRY (2017) a Stanford egyetemen végzett kutatásaiban igazolta, hogy a párhuzamos cselekvések károsítják az agyat, és csökkentik az IQ-t. McKEOWN (2014) Essentialism (A lényeg) címú múvében a „kevesebb több” mellett voksol. A 
szerzó szerint sokkal hasznosabb lenne egy dolgot csinálni, de azt jól, mint figyelmünket szétforgácsolva több dolgot végezni kétes minóségben.

A szabad- és a munkaidő összefüggéseit vizsgálta a már fentebb említett GFK globális marketingkutatással foglalkozó cég is, mely 2017 januárjában végzett felmérésében 7331 tizennyolc év feletti amerikai dolgozót kérdezett meg, akik fóállásban legalább heti 35 órát dolgoztak, és jogosultak voltak fizetett szabadságra. A kérdốiv 2598 fő́t talált, akik képesek voltak munkájukhoz a munkahelyükön kívül is hozzáférni, ezért az eredmények erre a mintegy két és félezer válaszadóra vonatkoznak. A felmérés feltárta, hogy a nyaralók $46 \%$-a dolgozik rendszeresen pihenése alatt, míg $27 \%$ alkalmanként, a másik $27 \%$ pedig egyáltalán nem végez munkával kapcsolatos tevékenységet. A kutatás következtetése szerint a nyaralás alatt rendszeresen munkát végzók $62 \%$-a a fizetett szabadságát sem veszi ki teljes mértékben, tehát halmozottan kevesebb lehetôsége van pihenésre. Ugyanakkor magas az aránya azoknak is, akik a nyaralás alatt ugyan nem dolgoznak, de hagynak bent szabadnapokat (52\%).

\subsection{A WORKCATION TURISTÁK TIPIZÁLÁSA}

A kutatás legfontosabb kérdésköre az utazás alatti stresszel kapcsolatos, ahol a megkérdezettek arról nyilatkoztak, hogy stresszesnek találják-e a nyaralás alatti munkavégzést, illetve stresszesek-e, ha nyaralás közben nem tudják használni a kommunikációs eszközeiket (2. ábra). A válaszok alapján négy különböző turista típust definiáltam. A kutatás pusztán turizmusfókuszú, az orvostudomány kompetenciájába tartozó vizsgálatot nem végeztem, és erre irányuló következtetést nem vontam le.

\section{Stresszes a munka miatt és stresszes a technika elérhetetlensége miatt}

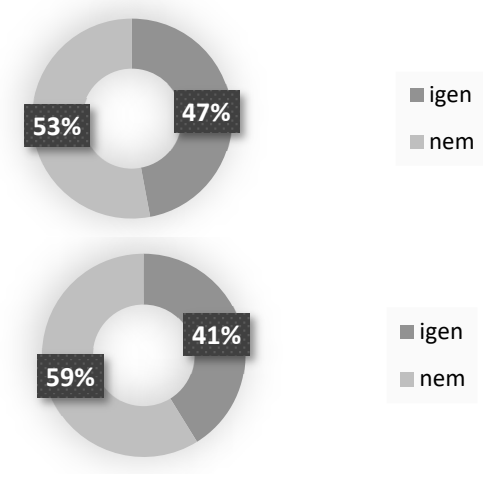

Forrás: saját szerkesztés
Jól látható, hogy nagyságrendileg megegyező azok aránya, akik a technikai elérhetóség miatt szoronganak, azokéval, akik a munka miatt streszszelnek a nyaralás alatt. Az eredmény munkavállalói és munkáltatói szempontból is aggodalomra ad okot, mivel azt sugallja, hogy a szabadságról visszajövők fele munkavégzéstől függetlenül nem tudott kikapcsolódni távolléte alatt. Ahhoz, hogy ezt a heterogén csoportot tipizálni lehessen, a nyaralási stressz okait, a kort és a foglalkozást vetettem össze, mely alapján négy fó csoportot definiáltam, melyeket kizárólag a szakirodalom alapján két altípussal egészítettem ki. A kategóriák vitaindító jellegúek, és ráépülő mélyelemzések során finomodhatnak és bővülhetnek.

\subsubsection{Stresszérzékeny turista}

A válaszadóknak mintegy 20\%-a számít kifejezetten stresszérzékenynek. A csoport egésze az X és az Y generációhoz tartozik. Foglalkozás területén nincs elhatárolható csoport.

Ezek az utazók mindkét esetben szoronganak, akár dolgozniuk kell, akár nem, ha a technikához való hozzáférésük nem ideális. Az ebbe a csoportba tartozó turisták nagy eséllyel képtelenek a szabadság alatt kiengedni, így épp olyan stresszesen térnek vissza munkahelyükre, mintha el sem mentek volna. Turizmus szempontjából a legnehezebben kielégíthetó csoport, mivel a modern technika biztosítása nem elegendô nyaralás alatti jóllétükhöz. Amennyiben egy támogató munkahelyi légkörben dolgoznak, a munkáltatónak és a munkavállalónak közösen kell kialakítania „rendelkezésre állás mentes" napokat, majd ezt kell fokozatosan kiterjeszteni először hétvégékre, később nyaralásokra.

\subsubsection{Technikafüggó turista}

A válaszadóknak mintegy 20\%-a tartozik ebbe a kategóriába. Fiatalabb korcsoportról van szó, a Z generáció és a diákok teljes csoportja sorolható ide.

Ez a típus elsősorban nem a munkavégzés kényszere miatt kerül stresszes állapotba, hanem a technikai feltételek nem ideális volta folytán. Ők azok, akik nem feltétlenül a munkatársakkal való kapcsolattartás miatt ellenőrzik állandóan telefonjaikat és egyéb eszközeiket, hanem megszokásból, esetleg önmaguk megnyugtatására. Turisztikai kínálat szempontjából nem jelentenek kihívást, az ingyenesen hozzáférhető modern technológia biztosítása már pozitív vendégelégedettséghez vezethet. 
Lektorált tanulmányok

\subsubsection{Munkafüggó turista}

A válaszadók 28\%-a tekinthetố munkafüggónek, elsôsorban az Y generáció tagjai. Foglalkozás területén nincs elhatárolható csoport.

Ez a típus a modern technológiai adottságok elótt is létezett, csak turisztikailag nem voltak megfoghatóak, mivel a múltban képtelenek voltak elutazni, hiszen igényeiket a turizmus oldaláról nehezen lehetett kielégíteni. Ók azok, akik a legmodernebb eszközökkel felszerelkezve érkeznek, így nincsenek ráutalva az adott szálláshely technikai felszereltségére. Számukra az utazási döntés fó szempontja az igényes környezet, mely a munkához nyugalmas hátteret és esztétikus díszletet biztosít, miközben segít fenntartani a nyaralás látszatát a maguk és a külvilág számára egyaránt.

\subsubsection{Stresszérzéketlen turista}

A válaszadók 32\%-a sorolható a stresszmentes turisták közé, minden 3. résztvevővel ez a legnépesebb csoport. Többnyire férfiak ( $80 \%$ ), illetve nagyobb arányban jelen vannak az X és a baby boomer generáció tagjai. Foglalkozás területén nincs elhatárolható csoport.

Ebbe a csoportba tartoznak azok a válaszadók, akik képesek nyaralási üzemmódba kapcsolni, és nem szoronganak akkor sem, ha a nyaraláshoz munkavégzés társul, vagy ha a technikához való elérhetőségük nincs biztosítva. Ez az a csoport, akik a munkatevékenységeket is képesek szervesen beilleszteni a szabadidós programjaikba. Ez a típus a nyaralás alatt a szabadidő́t csupán annyi munkával fúszerezi, mely számára a munkahelyen kívül eltöltött napokat stresszmentessé teszi. Turizmus szempontjából ideális turisták, mivel a munkával kapcsolatos kötelezettségeik nem befolyásolják nyaralási elégedettségük szintjét. Ebbe a csoportba soroltam a szakirodalom alapján beazonosítható két speciális alcsoportot.

- Modern luddita: a stresszérzéketlenek csoportján belül különül el ez a speciális csoport, mely nem a kutatás eredményeképpen meghatározható trend, hanem PENN-ZALESNE (2007) Microtrends címú múvében rajzolódik ki. Szerintük vannak bizonyos kreatív foglalkozást úzők, mint például az írók vagy múvészek bizonyos csoportja, akik tudomást sem vesznek a modern technika vívmányairól. Számukra hagyományos eszközeik, mint az írógép vagy a notesz és a toll használata az alkotási rituálé szerves része, mely akár a kreatív gondolatok születését is elősegítheti. Kissé meglepó módon az ô igényeik hasonlatosak a munkafüggő́k csoportjához, vagyis az esztétikus, inspiratív környezet a döntó, míg a technikai felszereltség elhanyagolható tényező. A múltban alkotótáborokban és múvésztelepeken (Dunakanyar, Balaton-part) gyứltek össze hasonlóan gondolkodó társaikkal. Magyarországon számos festői település válhat a ludditák számára ideális alkotó helyszínné, akár a régi tradíciókra alapozva, akár új fejlesztés eredményeként.

- Digitális nomád: szintén a stresszérzéketlenek csoportjához tartoznak, azonban a ludditák tökéletes ellentétei. Kettôs motivációval kelnek útra, így klasszikus értelemben vett szabadidős turistának sem tekinthetők. A turizmusban a digitális nomád jelentése: olyan személy, aki a modern technológiának köszönhetően helytôl függetlenül állandóan kapcsolódik a virtuális világhoz, mely által generált bevétel lehetôvé teszi számára az állandó vagy gyakori utazást. Ez a turista utazásai során egyszerú szálláshelyeket és kevés szolgáltatást vesz igénybe. A digitális nomád fó jellemzőinek kidolgozásához a BECOME NOMAD honlapot, valamint online interjúkat és riportokat dolgoztam fel (RUSSELL 2013, NOVA 2017), melyek alapján a 4. táblázatban látható ismérveket állítottam fel.

\section{A digitális nomád jellemzői}

\section{4. táblázat}

\begin{tabular}{|l|l|}
\hline \multicolumn{1}{|c|}{ Kategóriák } & \multicolumn{1}{c|}{ Jellemzök } \\
\hline Tartózkodási idő & $\begin{array}{l}\text { hosszabb tartózkodási idő } \\
\text { vörosi vagy ahhoz közeli }\end{array}$ \\
\hline Preferált környezet & helyhez nem kötött \\
\hline Munkakörnyezet & $\begin{array}{l}\text { a távolban élő ügyfélkör } \\
\text { ritmusához alkalmazkodnak }\end{array}$ \\
\hline Napi rutin & $\begin{array}{l}\text { életvitelük hasonul a } \\
\text { helyiekéhez }\end{array}$ \\
\hline Helyiekkel való viszony & $\begin{array}{l}\text { a turisták helyett a helyiekkel } \\
\text { és hasonló életvitelt } \\
\text { folytatókkal való kapcsolat }\end{array}$ \\
\hline Társadalmi élet & $\begin{array}{l}\text { lassú turista } \\
\text { modern technológia } \\
\text { szükséges }\end{array}$ \\
\hline Turista típusa & $\begin{array}{l}\text { kisebb, mint a hagyományos } \\
\text { turistáé }\end{array}$ \\
\hline Infrastruktúra igény & $\begin{array}{l}\text { alacsonyabb kategóriájú, } \\
\text { környezettudatosabb }\end{array}$ \\
\hline Ökológiai lábnyom & helyiekhez hasonló \\
\hline Szálláshely típusa & autentikus élmények \\
\hline Fogyasztói kosár tartalma
\end{tabular}

Forrás: saját szerkesztés

A digitális nomádok alapvetően tovább tartózkodnak a célterületen, ezért lassú turistának tekinthe- 
tők. A napi rutinjukban a munkavégzés elsősorban a távoli ügyfélkörükhöz, szabadidejük a helyiek szokásaihoz alkalmazkodik. A hosszabb tartózkodásnak köszönhetően előbb-utóbb új ismerősökre és barátokra is szert tesznek a helyiek körében. A digitális nomádok az urbánus tereket vagy a városokhoz közel található festői környezetet preferálják. A városi tér elsősorban a modern technológia miatt szükséges a számukra, másodsorban a kulturális és szórakozási lehetőségek igénye miatt. Továbbá a városi tereken nagyobb eséllyel találkoznak hasonló életvitelú emberekkel. A digitális nomádoknak - a tömegturistától eltérő életvitelük miatt - az ökológiai lábnyoma is kisebb, mértékét tekintve valahol a helyiek és a turisták között helyezkedik el. A konkrét pozíciót nagyban befolyásolják a lakhatási körülmények, mely lehet rövidtávú lakásbérlés vagy kereskedelmi szálláshely. Az ökológiai lábnyomra negatívan vagy pozitívan hat a használt közlekedési eszköz, így amennyiben intenzív gépkocsi használat realizálódik, a digitális nomád a hosszú tartózkodási idő pozitív hozadékát akár ki is olthatja. Ugyanígy, ha étkezése nem igazodik a helyi ízekhez, nem fogyaszt helyi ételeket, az általa generált élelmiszer import (szállítás) növeli az ökológiai lábnyom méretét.

\subsection{WORKCATION ÜDÜLÖHELY MINT FEJLESZTÉSI ALTERNATÍVA}

Ez a turisztikai termék elsősorban a stresszérzéketlenek csoportja számára lehet vonzó. Az alábbiakban a német gyakorlaton keresztül illusztrálom, hogy egy jól pozícionált workcation üdülőhely könynyen adaptálható a magyar vidéki viszonyokra, mivel nem kíván különleges adottságokat. A német Coconut Space üdülőhely Bad Belzig kisvárosban található, 90 km-re Berlintől. A 12 ezres történelmi város hivatalos gyógyhely, mely a Hoher Flaming Natúrpark közepén fekszik. Az üdülőhely változatos ajánlatokat kínál a kettős motivációjú turistáknak: egyéni és csoportos ajánlatai egy napra, egy hétre, illetve egy hónapra szólnak, melybe teljes ellátás, a közös terek használata, sport, spa és aktív programok is benne foglaltatnak. Az online bemutatkozásban nagy hangsúlyt helyeznek a nemzeti park nyújtotta nyugodt környezetre és a természetközeliségre, ugyanakkor a szálláshely a szórakozási lehetőségek tárházát (étterem, pub, sütögető) is biztosítja.

A német példához hasonló fejlesztés Budapest 60 km-es körzetében is megvalósítható, például a rövid szezonnal küzdő Velencei-tó környékén. Magyarországon egyelőre nincs másik nagyváros, mely nemzetközi turistákat nagyszámban vonzana, így vonzáskörzetük sem lenne megfelelő helyszín ilyen fejlesztéshez. Az alábbiakban összegyújtöttem a tó néhány jellemzőjét, mely alapján workcation úti céllá válhat.

- Nagyvárostól való távolság: 40 km;

- Megközelíthetőség: változatos közlekedési eszközökkel - gépkocsi, vasút, távolsági busz, kerékpár;

- Kulturális turizmus: történelmi emlékhelyek, Dinnyés Várpark, fesztiválok: EFOTT, Velencei karnevál a Korzón, Hal-, Vad- Borés Pálinkafesztivál:

- Gyógy- és wellness turizmus: Agárdi Gyógyés Termálfürdő, szállodák ajánlatai;

- Aktív turizmus: kerékpár túrák. Bárka, Capitol, Kunos, Nyerító lovardák programjai, Madárdal tanösvény, Expedíció kenutúrák;

- Szelíd turizmus: Velencei-tavi Madárrezervátumban madártani kutatások szakembereknek, Pákozd-Sukorói Arborétum és Vadasparkban séta, Dinnyés Fertő madárvonulás;

- Gasztroturizmus: pálinkafőzdék, sajtmúhelyek látogatása.

A fejlesztések a tavi turizmus három fő problémáját is kezelnék. Egyrészt megnyújtanák a turisztikai szezont, mivel a workcation turizmus nem kapcsolódik a fürdési szezonhoz. Továbbá javítanák a helyi vállalkozások jövedelmezőségét, melyek közül számos idényjelleggel múködik, egy szezonra felvett, gyakran tapasztalatlan munkatársakkal. Végül, hosszú távon enyhíthetne a Budapestet sújtó túlturizmuson (overtourism), mivel a workcation termék jól kombinálható konferenciaturizmussal.

\section{5. Összegzés}

A mai posztmodern társadalom egyik jól körvonalazható trendje a munka és a szabadidő közti határ elmosódása, melynek egyik turisztikai hozadéka a workcation (nyaralás alatti munkavégzés) jelenség terjedése. A tanulmány úttöróként a turizmus lencséjén keresztül vizsgálódik a témában, az elméleti és a gyakorlati síkot egyaránt érintve. Az elméleti fejtegetések során a workcation turizmus definiálására kerül sor, valamint a workcation turisták tipizálása is megtörténik.

A nyaralás alatti munkavégzés nyomán kialakult stressz alapján hat csoport különíthető el. A kutatás eredménye alapján jól körvonalazhatóak azok a csoportok, melyek igényeinek figyelembevételével egy adott település fenntartható turisztikai fejlesztéseket vihet végbe. Akár a modern ludditák, akár a digitális nomádok a vonzó célcsoport, a turisztikai kínálat kialakításakor érdemes a már létező külföldi jó gyakorlatok esettanulmányként 
való feldolgozása. A tanulmányban egy múködó külföldi gyakorlat rövid leírása után, a Velencei-tó, mint javasolt magyarországi helyszín bemutatására is sor került, melynek paraméterei további helyszínek kijelölésében is támpontot nyújthatnak.

\section{Felhasznált irodalom}

ARTHUR, C. (2012): How tablets are eating the PC's future - but might save the desktop computer. https://www.theguardian.com/ technology/2012/apr/25/tablet-pc-marketanalysis Letöltve: 2018. október 22.

AU, W. C. - AHMED, P. K. (2015): Exploring the Effects of Workplace Support on Work-life Experience: a Study of Malaysia. Human Resource Development International. 18. pp. 346- 365.

BAUMANN, Z. (2000): Liquid Modernity and Beyond. Cambridge: Polity.

BEIGI, M. - SHIRMOHAMMADI, M. (2017): Qualitative Research on Work-Family in the Management Field: A Review. Applied Psychology. 66(3). pp. 382- 433.

BRADBERRY, T. (2017): Why Smart People Do not Multitask. http://www.cnbc.com/2017/01/12/ why-smart-people-dont-multitask.html Letöltve: 2017. január 3.

CSÍKSZENTMIHÁLYI M. (2014): Az öröm múvészete. Budapest: Nyitott múhely.

DECI, E. L. - RYAN, R. M. (2008): Facilitating Optimal Motivation and Psychological Wellbeing across Life's Domains. Canadian Psychology. 49. pp. 14- 23.

ECO, U. (2017): Chronicles of a Liquid Society. - Faith, Hope and Clarity. Houghton Mifflin Harcourt.

FLEETWOOD, S. (2007): Why Work-life Balance Now? The International Journal of Human Resource Management. (18)3. pp. 387- 400.

FRICKER, R. D. (2012): Advantages and Disadvantages of Internet Research Surveys: Evidence from the Literature. https://core.ac.uk/download/ pdf/36731123.pdf Letöltve: 2018. október 20.

GILBERT, D. -ABDULLAH,J. (2004):Holidaytaking and the Sense of Well-being. Annals of Tourism Research. 31(1). pp. 103- 121.

HAAR, J. M. - RUSSO, M. - SUNE, A. - OLLIERMALATERRE, A. (2014): Outcomes of Worklife Balance on Job Satisfaction, Life Satisfaction and Mental Health: A Study across Seven Cultures. Journal of Vocational Behavior. (85)3. pp. 361- 373.

HOWARTH, F. (2015): Laptop vs. Tablet: How Each Device Drives Productivity. https:// insights.samsung.com/2015/06/19/laptop-vstablet-how-each-device-drives-productivityinfographic/ Letöltve: 2018. október 20.
HOUSTON, D. (ed) (2005): Work-Life Balance in the 21st Century. Basingstoke: Palgrave Macmillan.

JAMES, A. (2014): Work-life 'Balance' and Gendered (im)Mobilities of Knowledge and Learning in High-tech Regional Economies. Journal of Economic Geography. 14(3). pp. 483- 510.

MARAGATHAM, B. - AMUDHA, R. (2016): Work-life Balance of Women Bank Employees in Kumbakonam Municipal Precinct. Indian Journal of Science and Technology. 9(27). pp. 1- 7.

MARSHALL, J. (2012): Legal Opinion: Working while on Holiday. http://www.personneltoday.com/ $\mathrm{hr} /$ legal-opinion-working-while-on-holiday/ Letöltve: 2017. november 20.

McKEOWN, G. (2014): Essentialism. The Disciplined Pursuit of Less. Sunbury: Currency Publications.

MESSERSMITH, J. (2007): Managing Worklife Conflict among Information Technology Workers. Human Resource Management. 46(3). pp. 429- 451.

MICHALKÓG. (2010): A Boldogitóutazás. A turizmus és az életminőség kapcsolatának magyarországi vonatkozásai. MTA Földrajztudományi Kutatóintézet, Budapest.

MICHALKÓ G. - TEVELI-HORVÁTH D. SULYOK J. - KISS K. - JANCSIK A. (2014): A balkán(i)ság turisztikai reprezentációjának jólléti dimenziói. Turizmus Bulletin. 16(2). pp. 42- 50.

NAWIJN, J. - DAMEN, Y. (2014): Work during Vacation: Not so Bad after All. Tourism Analysis. 19(6). pp. 759- 767.

NEULINGER, J. (1982): Leisure lack and the quality of life: The broadening scope of the leisure professional. Leisure Studies. 1. pp. 53- 64.

NIPPERT-ENG, C. E. (1996): Home and Work: Negotiating Boundaries through Everyday Life. $1^{\text {st }}$ edition. University of Chicago Press.

NOVA, A. (2017): These Digital Nomads Have Ditched the 9-to-5 Life. https://www.cnbc. com/2017/10/17/these-digital-nomads-haveditched-the-9-to-5-life.html Letöltve: 2017. november 3 .

PENN, M. J. - ZALESNE, E. K. (2007): Microtrends: The Small Forces Behind Tomorrow's Big Changes. First Edition. New York: Twelve.

PIETERS, J. (2017): Nearly 70\% of Netherlands to take summer holiday; France, Spain top destinations. https://nltimes.nl/2017/06/14/ nearly-70-netherlands-take-summer-holidayfrance-spain-top-destinations Letöltve: 2018. szeptember 6.

RUSSELL, J. (2013): 7 'Digital Nomads' Explain How They Live, Work and Travel Anywhere in the World. https://thenextweb.com/insider/2013/12/15/7digital-nomads-explain-how-they-live-work- 
and-travel-anywhere-in-the-world/9/ Letöltve: 2017. november 3.

SARDESHMUKH, S. R. - SRINIVASAN, V. (2014): ICT and work-family balance: context of Indian software services. Labour \& Industry: a journal of the social and economic relations of work. http:// www.tandfonline.com/doi/full/10.1080/10301 763.2013.877119? scroll=top\&need Access=true Letöltve: 2017. november 30.

SILVERMAN, R. S. (2015): This Summer, How About a Workcation? http://www.wsj.com/ articles/this-summer-how-about-takinga-workcation-1435072989 Letöltve: 2016. november 3 .

STATT, N. (2015): The future of the tablet is the PC. https://www.cnet.com/news/the-future-of-thetablet-is-the-pc/ Letöltve: 2018. október 20.
SÜSS, S. - SAYAH, S. (2013): Balance between Work and Life: A Qualitative Study of German Contract Workers. European Management Journal. 31(3). pp. 250- 262.

TARI A. (2010): Y generáció. Budapest: Jaffa.

TARI A. (2011): Z generáció. Budapest: Tericum Kiadó. TITCOMB, J. (2017): Tablet sales to fall for third successive year as PC market stabilises. https:// www.telegraph.co.uk/technology/2017/01/11/ tablet-sales-fall-third-successive-year-pcmarket-stabilises/ Letöltve: 2018. október 20.

\section{Internetes forrás}

BECOME NOMAD: Digital Nomad Lifestyle - The Modern Nomads. http://becomenomad.com/digital-nomad-lifestyle/ Letöltve: 2017. március 20. 